Hispania, 2021, vol. LXXXI, n. ${ }^{\circ}$ 269, septiembre-diciembre, págs. 683-711 ISSN: 0018-2141, e-ISSN: 1988-8368, https://doi.org/10.3989/hispania.2021.017

\title{
Defender el Estado: la militarización del sistema de orden público en el segundo bienio republicano, 1933-1936*
}

\author{
Sergio Vaquero Martínez ${ }^{1}$ \\ Universitat de València \\ servama3@uv.es
}

RESUMEN: El objetivo del siguiente artículo consiste en analizar la militarización del sistema de orden público durante el segundo bienio republicano. El corpus de fuentes consultadas incluye la Gaceta de Madrid, el Diario de las Sesiones de Cortes, memorias, revistas policiales, prensa histórica y documentación archivística. Se defiende que su evolución dependió básicamente de cinco factores: los discursos gubernamentales sobre el orden público y la cultura profesional de guardias civiles y policias; el aparato legal y organizativo de seguridad; la presión sobre el Gobierno de partidos políticos, organizaciones patronales, grandes terratenientes, periódicos nacionales, cuerpos policiales y el Ejército, destacando la conducta de los border parties y la del presidente de la República; las diferentes políticas de orden público; y el control policial de la protesta y los principales episodios de violencia política. Se concluye que la militarización no

* Este artículo está financiado por una subvención para la contratación de personal investigador en fase postdoctoral (APOSTD/2021/360), sufragada por la Generalitat Valenciana y el Fondo Social Europeo. También forma parte del Proyecto I+D+i «Gobernabilidad, gobernanza y democratización. Un análisis desde debajo de la relación entre los poderes provinciales y locales y la ciudadanía durante la primera mitad de 1936» (PID2020-113986GB-I00), financiado por el Ministerio de Ciencia e Innovación.

Una versión preliminar fue presentada en el Seminario de Posgrado «El campo convulso. Conflictos en el mundo rural contemporáneo (1789-1945)», organizado por Óscar Bascuñán en la Facultad de Geografía e Historia de la Universidad Complutense de Madrid. Agradezco a Juan Pan-Montojo y al resto de participantes sus interesantes y certeros comentarios.

Siglas de archivos: Archivo Histórico Nacional, Madrid (AHN); y Archivo General de la Administración, Alcalá de Henares, Madrid (AGA).

${ }^{1}$ ORCID iD: https://orcid.org/0000-0002-0950-5334

Copyright: (C) 2021 CSIC. Este es un artículo de acceso abierto distribuido bajo los términos de una licencia de uso y distribución Creative Commons Reconocimiento 4.0 Internacional (CC-BY 4.0) 
fue un fenómeno constante ni irreversible, sino que hubo dos procesos distintos: uno de militarización entre septiembre de 1933 y diciembre de 1935, que se aceleró en octubre de 1934 y se desaceleró en abril de 1935, y otro de desmilitarización hasta febrero de 1936. Esta alternancia fue originada por la dialéctica entre dos modelos específicos de orden público: uno contrarrevolucionario y otro liberal.

Palabras Clave: Segunda República; segundo bienio; orden público; militarización; policía; represión.

Defending the state: the militarization of the public order system in the second Republican biennium, 1933-1936

ABSTRACT: The objective of the following article is to analyse the militarization of the public order system during the second Republican biennium. The corpus of consulted sources includes the Official Gazette of Madrid, the Record of Proceedings of the Spanish Parliament (Cortes), memoirs, police journals, historical press and archival documentation. I argue that its evolution basically depended on five factors: governmental discourse on public order and the professional culture of the civil guard and police; the legal and organizational security apparatus; the pressure on the government from political parties, employers' organizations, big landowners, national newspapers, police forces, and the Army, particularly the behaviour of the border parties and the president of the Republic; the different public order policies; and the policing of collective protest and major episodes of political violence. I conclude that militarization was neither a constant nor an irreversible phenomenon, but that two dissimilar processes were taking place: a militarization process between September 1933 and December 1935, that was accelerated as of October 1934 and decelerated as of April 1935, and then a demilitarization process until February 1936. This alternation was produced by the dialectic between two specific models of public order: one counterrevolutionary and the other liberal.

KEY WORDS: Second Republic; second biennium; public order; militarization; police; repression.

CÓMO CITAR ESTE ARTÍCULO / CITATION: Vaquero Martínez, Sergio, «Defender el Estado: la militarización del sistema de orden público en el segundo bienio republicano, 1933-1936», Hispania, 81/269 (Madrid, 2021): 683-711. https://doi.org/10.3989/ hispania.2021.017.

\section{INTRODUCCIÓN}

El bienio radical-cedista ha sido conocido hasta hace relativamente poco como el «bienio negro», una etapa caracterizada por un viraje militarista en la administración del orden público que trajo consigo una escalada de la represión 
del obrerismo de clase $e^{2}$. Los especialistas en esta temática han identificado múltiples componentes de este fenómeno: la constante declaración de estados de excepción, el intervencionismo del Ejército y la expansión de la jurisdicción castrense $^{3}$; la no renovación del funcionariado y la connivencia entre terratenientes y guardias civiles en el medio ural $^{4}$; las políticas contrarreformistas de orden público, la militarización de los cuerpos policiales y la pretensión gubernativa de asegurarse su respaldo político ${ }^{5}$; la identificación del orden público con la defensa del principio de autoridad, la cultura castrense de las fuerzas de seguridad y el influjo de los feroces repertorios coloniales $^{6}$; la movilización huelguística y la radicalización revolucionaria de los socialistas ${ }^{7}$; unos discursos gubernamentales sobre el orden público que legitimaban diversos grados de militarización ${ }^{8}$; y el contencioso entre los Ministerios de Gobernación y Guerra por controlar el aparato securitario?.

El número de variables es tan elevado que resulta difícil comprender el qué, el cómo y el porqué de este proceso al no quedar claro cuáles fueron las más relevantes ni mediante qué mecanismos se interrelacionaron. Ciñéndonos a un plano esencialmente nacional, nuestro propósito consiste en sistematizar qué factores tuvieron mayor incidencia causal, subrayando su carácter contingente y la preponderancia de la agencia sobre las estructura ${ }^{10}$. Se defenderá que dicho fenómeno puede explicarse aplicando un modelo teórico, inspirado en el diseñado por Donatella della Porta y Herbert Reiter, que considere cinco elementos $^{11}$ : los discursos gubernativos sobre el orden público y la cultura profesional de guardias civiles y policías; el aparato normativo y organizativo de seguridad; la presión sobre el Gobierno de partidos políticos, asociaciones patronales, grandes terratenientes, periódicos nacionales, cuerpos policiales y el Ejército; las diferentes políticas de orden público; y el control policial de la protesta colectiva y los principales episodios de violencia política. Siguiendo a Giovanni Capoccia, influido a su vez por Juan Linz, se resaltará la conducta de los border parties o partidos semileales, que ocupaban un espacio adyacente a los partidos extremistas, respecto a las tentativas del Ejecutivo de formar coa-

2 VIDARTE, 1978.

${ }^{3}$ BALLBÉ, 1985: 363, 368 y 378.

${ }^{4}$ LÓPEZ MARTÍNEZ, 1995: 119 y 69.

5 BLANEY, 2007: 49-50. PALACIOS CEREZALES, 2011: 626-628.

${ }^{6}$ GONZÁLEZ CALLEJA, 2014: 52-53 y 57.

7 REY, 2008: 379.

8 VAQUERO MARTÍNEZ, 28 (Madrid, 2016).

9 MERA COSTAS, 2015: 178-222.

${ }^{10}$ Un estudio que enmarca la represión de la insurrección asturiana en el debate internacional sobre la brutalización de la política en CHAMBERLIN, 2020.

${ }^{11}$ DELLA PORTA y REITER, 1998. 
liciones alternativas para consolidar el régimen, y el papel del presidente de la República $^{12}$. Entenderemos por sistema de orden público:

... el conjunto de los medios materiales y organizativos, conocimientos, procesos de decisión y formas pautadas de actuación que configuran la aplicación de la coerción estatal ante las protestas colectivas, con la función de garantizar que las decisiones de los poderes del Estado resulten vinculantes. Es decir, vinculantes de hecho, y no sólo de derecho ${ }^{13}$.

Su militarización será definida como la asimilación e implementación de las tareas, las pautas organizativas y los patrones de conducta del Ejército, así como todo lo relacionado con la preparación para la guerra, por parte de las fuerzas de orden público. Este proceso tuvo lugar mediante dos vías: la aplicación de políticas contrarreformistas y la socialización en valores, ideas y creencias castrenses. Según Diego López Garrido, la persistencia del militarismo en la España liberal se debió, precisamente, al fuerte centralismo del Estado y al mantenimiento de una administración de seguridad militarizada. Este modelo se fundamentaba en la ocupación militar del territorio, el desarrollo de las fuerzas represivas sobre las preventivas y un continuum entre Ejército y policía en tres niveles: los militares mantenían un rol central en la gestión del orden, especialmente durante los estados de excepción; la Guardia Civil era un cuerpo militar, hegemónico en el aparato de seguridad, que guardaba un estrecho vínculo con el Ejército; y los oficiales del Cuerpo de Seguridad procedían enteramente de sus filas. En consecuencia, el sistema de seguridad heredado por la República estaba mediatizado por una cultura militar basada en una doctrina de defensa nacional, que tendía a magnificar al enemigo interno y desviar al Ejército de su función de defensa exterior ${ }^{14}$.

\section{ROBUSTECER LA AUTORIDAD: LA CONTRARREFORMA DE LA ADMINISTRACIÓN DE SEGURIDAD}

Los malos resultados de la coalición gobernante en las elecciones de vocales del Tribunal de Garantías Constitucionales decidieron a Niceto Alcalá Zamora a sustituir a Manuel Azaña por Alejandro Lerroux, primero, y por Diego Martínez Barrio, después, debido a que el Gobierno que aquel organizó el 12 de septiembre de 1933 no fue refrendado por un Parlamento que le era «hostil». El 9 de octubre, el político sevillano encabezó otro gabinete, cediéndole la cartera

12 CAPOCCIA, 2007: 16-17.

13 PALACIOS CEREZALES, 2008: 2.

${ }^{14}$ LLEIXÀ, 1986: 21-30. LÓPEZ GARRIDO, 1987: 64-71. CRUZ, 10-11 (Salamanca, 1992-1993): 219. 
de Gobernación a Manuel Rico Avello ${ }^{15}$. Este ministro desmanteló los pilares de la reforma policial emprendida durante el bienio anterior. Para comenzar, facilitó el retorno de los pocos guardias y policías que habían sido depurados, aprobando una «amnistía policial» que declaró sobreseídos los expedientes en tramitación no motivados por faltas graves, y canceló los correctivos de multas, suspensiones de empleo y sueldo y descensos en el escalafón ${ }^{16}$. Posteriormente, la Sección Especial que se había constituido para reducir la autonomía de la Dirección General de la Guardia Civil, reconvertida en «Inspección General», pasó a depender de este organismo y su personal civil fue sustituido por miembros del instituto ${ }^{17}$. El Gobierno satisfizo así al personal de la Benemérita, que veía aquella reforma como una desnortada intromisión del poder civil en asuntos privativos del estamento militar ${ }^{18}$.

La llegada de los radicales al poder conllevó un cambio de repertorio de control policial de la protesta. A finales de septiembre, Lerroux confió la jefatura de la Guardia de Asalto a Agustín Muñoz Grandes. El teniente coronel minimizó sus atributos civilistas e impuso un protocolo más castrense, semejante al de la Benemérita, basado en un empleo más habitual de la fuerza y las descargas de fusilería. El proceso se completaría en marzo, cuando las órdenes restrictivas referentes al uso de las armas fueron suplidas por la de llevarlas cargadas y desenfundadas hasta en las camionetas ${ }^{19}$. Esto coartó drásticamente el derecho de manifestación y huelga de las asociaciones de clase, si bien las cargas a porrazos no desaparecieron, puesto que se utilizaron durante la huelga general de la construcción de octubre pese a que las reyertas entre cenetistas y ugetistas se cobraron varias vidas ${ }^{20}$. Por norma, su empleo se reservó para protestas cuya represión conllevaba un mayor coste político, principalmente las huelgas universitarias.

Esta línea contrarreformista se intensificó a causa del resultado de las elecciones generales del 19 de noviembre. Los partidos de izquierdas obtuvieron 2.804.695 votos (33\%), los de centro 1.647.271 (19,5\%) y las derechas 4.028.749 (47,5 \%). La gran vencedora fue la Confederación Española de Derechas Autónomas (CEDA), que obtuvo 115 escaños, seguida por el Partido Republicano Radical, que logró 101, y a mayor distancia por los Partidos Socialista (59) y Agrario (30) ${ }^{21}$. El bloque mayoritario quedó compuesto por radicales, cedistas, agrarios, liberal-demócratas, progresistas y algunos diputados independientes.

\footnotetext{
15 MARTÍNEZ BARRIO, 1983: 191-204. TOWNSON, 2002: 219-222.

16 Gaceta de Madrid, 288, 15 de octubre de 1933: 414-415. BLANEY, 2007: 50.

17 Gaceta de Madrid, 292, 19 de octubre de 1933: 489-491.

18 Revista Técnica de la Guardia Civil, Madrid, noviembre de 1933: 409-410.

19 PALACIOS CEREZALES, 2011: 627-628.

20 SOUTO KUSTRÍN, 2004: 102.

${ }^{21}$ VILLA GARCÍA, 2011: 348-349 y 489-490.
} 
Sin embargo, el inconstante respaldo que Gil Robles brindó a sus socios de Gobierno por su competencia con la extrema derecha monárquica provocó una inestabilidad crónica. No por casualidad, casi todas las crisis ministeriales estuvieron originadas, junto a otros factores, por desavenencias referentes al mantenimiento del orden.

La Confederación Nacional del Trabajo intentó evitar la alternancia en el poder lanzándose a la revolución por tercera vez. El movimiento prendió el 8 de diciembre en Aragón, La Rioja, Extremadura, Andalucía, Cataluña, León y el País Valenciano. Los anarquistas colocaron explosivos, sabotearon las líneas de ferrocarril —en Puzol, mataron a trece personas-, asaltaron multitud de casas-cuarteles e incendiaron archivos municipales, mientras que el Gobierno declaró al estado de alarma y recurrió al Ejército. 75 anarquistas, 11 guardias civiles y tres guardias de Asalto murieron y hubo, además, cientos de heridos y detenidos, algunos de los cuales fueron torturados. Los sucesos más luctuosos acontecieron en Villanueva de la Serena: el sargento Pío Sopena y varios rebeldes fueron asediados en la Caja de Reclutamiento por fuerzas policiales y militares, que los bombardearon con ametralladoras, morteros y un cañón. Todo terminó con un violento asalto de los guardias de dicho nombre - se rumoreó que cuatro jóvenes fueron fusilados-, quedando en total dos guardias civiles y ocho rebeldes muertos ${ }^{22}$.

Las garantías constitucionales apenas estuvieron vigentes plenamente durante el segundo bienio. La Ley de Orden Público permitía declarar tres estados de excepción: prevención, que posibilitaba adoptar medidas no aplicables en régimen normal pero sin vulnerar formalmente los derechos constitucionales - a efectos prácticos, sin embargo, su vigencia se veía seriamente comprometida-; alarma, que permitía suspender los derechos de habeas corpus, movilidad, expresión, reunión, asociación y sindicación; y guerra, durante el cual las autoridades militares asumían el mando y los civiles eran juzgados por consejos de guerra y no por tribunales de urgencia como en los dos anteriores ${ }^{23}$. Dichos estados fueron declarados, prorrogados o sustituidos 48 veces: 15 en todo el territorio nacional y 33 en una o varias regiones o provincias, 19 de las cuales afectaron a todas ellas de manera diferenciada. 16 veces lo fue el de prevención, 22 el de alarma y 10 el de guerra. El estado de prevención estuvo vigente total o parcialmente del 12 de septiembre al 17 de octubre y del 2 al 8 de diciembre de 1933, del 6 de enero al 6 de marzo y del

22 CASANOVA, 2010: 102 y 115-123. AHN, Gobernación, serie A, legajo 58, expediente 27. GONZÁLEZ CALLEJA, 2015: 354. TOWNSON, 2011: 110-115.

${ }^{23}$ Gaceta de Madrid, 211, 30 de julio de 1933: 682-690. Los ciudadanos también eran juzgados en consejos de guerra en régimen de normalidad cuando agredían física o verbalmente a funcionarios considerados "fuerza armada», como guardias civiles, carabineros o, en supuestos de rebelión o sedición, guardias de Seguridad. 
24 de junio al 22 de septiembre de 1934, y del 1 de marzo de 1935 al 6 de enero de 1936 (506 días de un total de 890); el de alarma del 9 de diciembre de 1933 al 5 de enero de 1934, del 7 de marzo al 23 de junio y del 23 de septiembre al 5 de octubre de 1934, del 23 de enero de 1935 al 6 de enero de 1936 y del 17 al 18 de febrero del último año (501 días); y el de guerra estuvo vigente del 6 de octubre de 1934 al 12 de abril de 1935 y del 28 de junio al 26 de septiembre de 1935 (280 días). Por tanto, solo hubo normalidad constitucional entre el 18 de octubre y el 1 de diciembre de 1933 y entre el 7 de enero y el 16 de febrero de 1936 ( 86 días) ${ }^{24}$.

El 16 de diciembre, ignorando las peticiones de algunos dirigentes republicanos de izquierda y socialistas para que impidiera la constitución de las nuevas Cortes, Alcalá Zamora le ofreció nuevamente a Lerroux formar Gobierno. El presidente mantuvo a Rico Avello en Gobernación, aunque lo sustituiría el 23 de enero por Martínez Barrio ${ }^{25}$. Pese a su profunda disconformidad, el Ejecutivo siguió adelante con la transferencia de competencias de seguridad a la Generalitat de Cataluña, acordada durante la etapa anterior. Martínez Barrio había ordenado el traspaso de los servicios de los Cuerpos de Investigación y Vigilancia y de Seguridad y Asalto, cuyos miembros podrían decidir entre servir al Estado o a la Generalitat. No obstante, había subrayado el carácter castrense del segundo cuerpo, indicando que «por ser una fuerza organizada militarmente y sujeta al Código de Justicia militar» en lo referente a la disciplina y subordinación al mando, continuaría dirigido por oficiales del Ejército y los institutos armados ${ }^{26}$. Expandiendo la esfera militar de la administración, el Gobierno pretendía limitar el alcance de la descentralización en su vertiente civil. Poco después, Lerroux ordenó la transferencia de los servicios de la Guardia Civil, especificándose que sus hombres seguirían sujetos a su Cartilla y reglamentos y que las autoridades civiles no podrían mezclarse en sus «interioridades» materiales o personales ni sancionar sus faltas. Aunque su descentralización fue más limitada, la medida era revolucionaria, como indica Manel Risques, considerando el tradicional centralismo de la Benemérita ${ }^{27}$. El proceso culminó con el traspaso de los Mossos d'Esquadra y los Somatenes que, contrariamente, implicó cierta desmilitarización. Aunque aquellos mantuvieron idénticos atributos castrenses que el Cuerpo de Seguridad, ambas fuerzas

${ }^{24}$ Estas cifras se han calculado utilizando exclusivamente la Gaceta de Madrid. Un estudio mucho más minucioso en GONZÁLEZ CALLEJA, 2014: 205-208 y 327-334.

${ }^{25}$ LERROUX, 1985: 119 y 144-145. TOWNSON, 2002: 237-238.

${ }^{26}$ Gaceta de Madrid, 320, 16 de noviembre de 1933: 1082-1084.

${ }^{27}$ Gaceta de Madrid, 343, 9 de diciembre de 1933: 1654-1656. RISQUES CORBELLA, 2012: 187. 
dejaron de depender parcialmente del ministro de la Guerra y el Somatén del general de la IV División ${ }^{28}$.

La creciente militarización también se materializó en los premios que la fuerza pública recibió por su papel en la sublevación ácrata. El 14 de diciembre fueron declarados «hechos de guerra» dichos sucesos para el personal del Ejército, la Guardia Civil y el Cuerpo de Seguridad que había resultado muerto o herido o se había distinguido cumpliendo con su deber, lo que reportaba a los interesados y sus familiares los beneficios del reglamento de recompensas en tiempo de guerra ${ }^{29}$. La inclusión del último cuerpo, cuya naturaleza era civil no obstante sus innegables rasgos militares, constituía una significativa novedad. La medida, que se extendió a ciertos episodios acontecidos entre abril de 1931 y marzo de 1932, fue acogida favorablemente por los policías, que entendían que corregía una secular desigualdad respecto a la Benemérita ${ }^{30}$.

Aprovechando el cambio de Gobierno, los grandes propietarios denunciaron con enorme tremendismo la «anarquía» reinante en el campo, propiciando así la aplicación de una política más coercitiva contra los socialistas. Estos, por su parte, condenaron aquella «persecución» y recurrieron a formas de protesta más tradicionales y virulentas (invasiones de fincas, robos de aceitunas, roturaciones ilegales, destrucciones de cosechadoras... $)^{31}$. En paralelo, la radicalización de la izquierda obrera y la irrupción de Falange originaron una espiral de atentados que se prolongaría hasta octubre de 1934. Por mencionar únicamente los casos más sonados de la capital, el 9 de febrero Matías Montero fue asesinado por el socialista Francisco Tello, el 10 de junio unos falangistas mataron a Juanita Rico e hirieron a tres compañeros suyos cuando volvían de un acto de las juventudes socialistas, y el 29 de agosto el dirigente de la juventud comunista Joaquín de Grado murió en una reyerta contra otros falangistas en Cuatro Caminos $^{32}$.

\section{LA DEFENSA DEL Estado: FORTALECIMIENTO, CENTRALIZACIÓN, CONTRARREVOLUCIÓN}

La defección del ala izquierda del Partido Radical, derivada de su desconfianza respecto al accidentalismo de la CEDA, conllevó la dimisión de Martínez Barrio y su remplazo, a primeros de marzo de 1934, por Rafael Salazar

${ }^{28}$ Gaceta de Madrid, 26, 26 de enero de 1934: 650-651.

29 Gaceta de Madrid, 349, 15 de diciembre de 1933: 1834.

${ }_{30}$ Gaceta de Madrid, 358, 24 de diciembre de 1933: 2109. Policía Española, Madrid, 16 de diciembre de 1933: 16.

${ }^{31}$ REY, 2008: 342-347 y 381.

32 GONZÁLEZ CALLEJA, 2015: 356. SOUTO KUSTRÍN, 2004: 140-142. 
Alonso $^{33}$. Su política de fortalecimiento del Estado y mayor intransigencia frente a los socialistas le valieron el respaldo de Gil Robles y una mejor imagen entre las organizaciones patronales, especialmente desde la huelga de Artes Gráficas y el decidido apoyo que brindó al marqués de Luca de Tena ${ }^{34}$. Esta estrategia, por contra, le reportó también la oposición de Alcalá Zamora, que obstaculizaría sistemáticamente su puesta en práctica.

La legitimación de esta política descansó en un discurso del orden público de tipo contrarrevolucionario. Salazar Alonso sostenía que el leitmotiv del Gobierno era «defender el Estado» y «mantener el principio de autoridad», por lo que su misión era «dar una sensación de energía en defensa del Estado, en defensa de la República, que es decir en defensa de España». Entendía que transferir el orden público a la Generalitat era un «gran peligro» y que la Guardia Civil no era un «instrumento de terror», pero sí «de respeto, aunque llegue al límite del miedo». El ministro pretendía restituir su «interior satisfacción», carcomida por los «rozamientos» con los alcaldes socialistas y la «inactividad» que les ordenaban ante los ataques de sus seguidores, para que la Guardia Civil fuera «ante todo, Guardia civil». Igualmente, creía necesario edificar una «organización contrarrevolucionaria», integrada por ciudadanos de estratos sociales acomodados, que respaldara al Ejecutivo, porque no debía haber un «Estado de clase», sino uno que mantuviera «el derecho de todos». Cualquier huelga contraria al Gobierno y a las Cortes era, en su opinión, «ilegal» y «revolucionaria» y, como sucedía con la guerra, la Constitución debía incorporar el «principio de renuncia» a la misma. No resulta extraño, pues, que se imaginara gobernando constantemente «bajo el signo de la revolución» ${ }^{35}$ :

... ya no se trata de luchas entre partidos, ni de posiciones políticas. Hay que clasificarse en uno de los dos bandos que dividen a España. O revolución o contrarrevolución. Los que quieren la conservación de la sociedad y del orden, los que desean la paz y crean en la necesidad de mantener el Estado, deben estar a su lado; los enemigos del Estado, al otro ${ }^{36}$.

El ministro incrementó todavía más la autonomía de la Guardia Civil. El día 7 de marzo se declaró el estado de alarma en todo el territorio y, el 10, se eliminó la Secretaría Técnica instituida el año anterior para coordinar los servicios de la Benemérita y la Policía, constituyendo en su lugar otro negociado en

${ }^{33}$ LERROUX, 1985: 173-174.

${ }^{34}$ CABRERA CALVO-SOTELO, 1983: 241. SALAZAR ALONSO, 1935: 63.

${ }_{35}$ Diario de las Sesiones de Cortes, 46, 7 de marzo de 1934: 1348 y 1357-1358. Diario de las Sesiones de Cortes, 49, 13 de marzo de 1934: 1497. SALAZAR ALONSO, 1935: 34-35, 81, 146-148, 271 y 346.

${ }^{36}$ SALAZAR ALONSO, 1935: 267. 
la Inspección General ${ }^{37}$. Por su parte, las Cortes sancionaron una ley que ampliaba la plantilla del instituto en 1.200 guardias de segunda y la Guardia de Asalto en otros $1.000^{38}$. Asimismo, se restableció el traspaso de los tenientes del Ejército a la Benemérita anulando la supresión temporal de su ingreso como oficiales hasta que quedaran amortizados los alféreces del instituto, aunque se restauró la clásica proporcionalidad que reservaba dos tercios a la Guardia Civil y uno al Ejército, en lugar de la inversa que, curiosamente, había dispuesto Azaña ${ }^{39}$.

Tras un bronco debate que se cobró la dimisión del ministro de Justicia, Ramón Menéndez Valdés, el 24 de abril resultó aprobada la Ley de Amnistía. Fueron perdonados ciertos delitos sociopolíticos cometidos hasta el día 14, salvo los de rebelión y sedición no militares, cuya fecha se fijó el 3 de diciembre de 1933, excluyendo así la pasada insurrección. Como se pretendía, fueron excarcelados los condenados por la Sanjurjada y reingresaron los guardias y militares que habían sido separados ${ }^{40}$. Por otro lado, al día siguiente se extendió a todo el país el estado de alarma declarado en Zaragoza y Valencia ${ }^{41}$. Por añadidura, además de facilitar el rearme de los ciudadanos de orden, Salazar Alonso concedió licencias gratuitas al personal retirado o en la reserva de la Guardia Civil, los Carabineros y los Cuerpos de Seguridad y Vigilancia. Esto lo completó con otra orden que autorizaba a los guardias de Seguridad a ir armados cuando no llevaran uniforme. De esta manera, aumentando el número y la disponibilidad de sus efectivos, pretendía reforzar la dimensión más represiva del aparato de seguridad ${ }^{42}$.

La amnistía motivó un tenso enfrentamiento entre el Gobierno y el presidente de la República. Alcalá Zamora se negó a firmarla y, cuando lo hizo, adicionó una nota exponiendo su oposición. Sintiéndose desacreditado, Lerroux dimitió y aquel le ofreció su cargo a Ricardo Samper, que obtuvo la autorización del caudillo radical a condición de que mantuviera a Salazar Alonso ${ }^{43}$. Esto daría pie a numerosos conflictos porque el talante de Samper era considerablemente más liberal que el de su predecesor.

El principal episodio de protesta anterior a octubre fue la huelga general convocada el 5 de junio por la Federación Española de Trabajadores de la Tierra. Días antes, Salazar Alonso promulgó el estado de alarma, declaró la cosecha «servicio público nacional» y anunció que se ilegalizarían las huelgas y los

${ }^{37}$ BALLBÉ, 1985: 364. Gaceta de Madrid, 72, 13 de marzo de 1934: 1948. Gaceta de Madrid, 73, 14 de marzo de 1934: 1972.

${ }^{38}$ Gaceta de Madrid, 81, 22 de marzo de 1934: 2187.

39 Gaceta de Madrid, 82, 23 de marzo de 1934: 2216-2217.

${ }^{40}$ Gaceta de Madrid, 115, 25 de abril de 1934: 548-549.

${ }^{41}$ BALLBÉ, 1985: 364.

42 VAQUERO MARTÍNEZ, 2018: 368.

43 ALCALÁ ZAMORA, 1977: 272-274. TOWNSON, 2002: 259-260. 
lock-outs, se prohibirían las manifestaciones y propagandas del paro, los diarios no sometidos a censura previa serían multados y los gobernadores civiles disolverían las reuniones, deteniendo a sus participantes ${ }^{44}$. Intentó también declarar el estado de guerra, pero Alcalá Zamora no lo consintió ${ }^{45}$. La huelga fue proclamada en 1.563 pueblos: la mitad de los de Ciudad Real, Córdoba y Málaga, y la cuarta parte de los de Badajoz, Huelva y Jaén. El saldo final fue de 14 muertos, 200 heridos y 25.000 detenidos. Aunque los huelguistas actuaron pacíficamente por lo general, hubo coacciones y agresiones contra esquiroles, destrucción de segadoras, incendios de las cosechas y enfrentamientos con los serenos. A su vez, las fuerzas policiales cerraron numerosas casas del pueblo, detuvieron a sus directivos y dispararon contra los campesinos. Los hechos más trágicos ocurrieron en Alconchel: un cabo fue apuñalado durante una discusión contra decenas de huelguistas y sus compañeros abrieron fuego, matando a tres personas e hiriendo a otras cuatro ${ }^{46}$.

A raíz de la huelga, Salazar Alonso aceleró su política de recentralización municipal. Además de sustituir 193 ayuntamientos por comisiones gestoras dominadas por partidos derechistas, reforzó su control de las policías locales y auxiliares ${ }^{47}$. El 11 de julio dispuso que en la DGS y los Gobiernos civiles hubiera registros de los guardias municipales, serenos, vigilantes y porteros, obligando a los primeros a renovar sus licencias de armas, que podrían ser suspendidas por los gobernadores. Todos obtenían la consideración de agentes de la autoridad, lo que recrudecía el castigo de los que se les resistieran o atentaran contra ellos, pero también el suyo cuando fueran negligentes o desobedecieran las órdenes ${ }^{48}$. Gracias a esta medida, el ministro pudo acelerar la depuración y sustitución de las policías municipales nombradas por los alcaldes socialistas recurriendo a la clientela de las élites locales. A fin de cuentas, durante la República su contratación no había dejado de estar determinada por el caciquismo y el favoritismo político, independientemente del signo de los ayuntamientos ${ }^{49}$.

Antes de dimitir, Salazar concedió aún más independencia a la Guardia Civil mediante una reorganización que rectificaba la de Casares del 28 de julio de 1933. El aumento del número de Tercios de 19 a 23, la equiparación en categoría de todas las Comandancias y el traslado de las Mayorías de las Zonas no ya a los Tercios, donde estaban antes, sino a las Comandancias, mucho más numerosas, agravaba dos problemas que Azaña había intentado mitigar:

${ }^{44}$ Gaceta de Madrid, 146, 26 de mayo de 1934: 1300. Gaceta de Madrid, 150, 30 de mayo de 1934: 1387-1389. AGA, Interior, caja 44/02421, legajo 1.

45 SALAZAR ALONSO, 1935: 165.

46 AHN, Gobernación, serie A, legajo 50, expediente 10. ESPINOSA MAESTRE, 2007: 70-71 y 340. COBO ROMERO, 2007: 252-272.

47 SALAZAR ALONSO, 1935: 122-123.

48 Gaceta de Madrid, 194, 13 de julio de 1934: 471-472.

49 PALACIOS CEREZALES, 2011: 617. 
aumentaba el número de jefes y oficiales y favorecía cierta descentralización orgánica que resultaba paradójica considerando que el cuerpo era el principal símbolo del centralismo estata ${ }^{50}$. De otra parte, para contener la politización de la juventud y la radicalización de ciertas organizaciones, se restringió la movilización de los jóvenes: los menores de 16 años no podrían ingresar en entidades políticas y los menores de 23 necesitarían autorización de sus padres o tutores $^{51}$. Para concluir, el 23 de septiembre el Ejecutivo declaró el estado de alarma en todo el país ${ }^{52}$.

\section{LA GUERRA CONTRA LA REVOLUCIÓN: MILITARIZACIÓN POLICIAL Y «PACIFICACIÓN» DEL TERRITORIO}

A primeros de octubre sobrevino otra crisis de gabinete desencadenada por Gil Robles, que se resolvió con la incorporación de tres miembros de su partido: Rafael Aizpún, Manuel Giménez Fernández y José Anguera de Sojo. Alcalá Zamora se vio obligado a aceptarlo y volvió a encargarle el Gobierno a Lerroux, aunque forzándole a sustituir a Salazar Alonso por el radical Eloy Vaquero $^{53}$. Interpretando el ascenso de la CEDA como una provocación y una amenaza, los socialistas cumplieron lo prometido y declararon la huelga revolucionaria. El momento para el que llevaban preparándose meses, organizando milicias y adquiriendo armas clandestinamente, había llegado.

La insurrección afectó principalmente a Asturias, Cataluña, Palencia, León, Vizcaya y Madrid. En la segunda región intervinieron tres actores: la Generalitat presidida por Lluís Companys, Estat Català y sus escamots, y la Alianza Obrera y los rabassaires. Proclamado el Estado Catalán dentro de la República Federal Española, el general Batet, desoyendo las órdenes de Diego Hidalgo, consiguió que los rebeldes se rindieran la madrugada del 7, un día antes del desembarco de las huestes africanas; todavía así, los sucesos produjeron 103 muertes en Cataluña. En Asturias, el conflicto exhibió los atributos formales de una guerra civil, según Eduardo González Calleja. Las fuerzas obreras constituyeron un embrionario «ejército rojo», organizaron grupos parapoliciales y recurrieron a la guerrilla urbana. Columnas de milicianos tomaron las cuencas mineras y marcharon a conquistar Oviedo, asaltando las casas-cuarteles de la Guardia Civil y asesinando a varios paisanos, la mayoría religiosos. La contraofensiva del Ejército, comandada por el general López Ochoa, desembocó en sangrientos combates seguidos de maltratos, torturas y fusilamientos

${ }^{50}$ Gaceta de Madrid, 187, 6 de julio de 1934: 187-188.

${ }^{51}$ Gaceta de Madrid, 243, 31 de agosto de 1934: 1893-1894.

52 BALLBÉ, 1985: 364.

53 GIL ROBLES, 1968: 136-139. TOWNSON, 2002: 309-311. 
perpetrados generalmente por los legionarios y regulares del teniente coronel Yagüe. El balance oficial, contabilizado manifiestamente a la baja, fue de 1.084 muertos - 855 civiles y 229 militares y policías — en Asturias y $1.335-1.051$ y 284, respectivamente - en toda España. Cabe añadir que de los 2.629 asesinatos que cuenta dicho autor para el periodo republicano, 1.705 acontecieron en este bienio y, de estos, 1.054 (61,8\%) fueron responsabilidad de las fuerzas estatales $^{54}$.

El Gobierno adoptó ante la sublevación una estrategia inequívocamente bélica. En principio, transfirió el poder a las autoridades castrenses declarando el estado de guerra y el ministro del ramo le pidió al general Franco que asumiera el control de las operaciones ${ }^{55}$. Seguidamente, autorizó la cooperación de los soldados disponibles y oficiales y clases de complemento y retirados como «reserva de las fuerzas vivas» $»^{56}$. A continuación, fueron militarizados los guardias y agentes municipales que prestaran servicios durante aquel estado, siendo considerados «fuerza armada $»^{57}$. Como resultado, la justicia castrense experimentó una expansión sin parangón: hasta la amnistía, buena parte de los miles de detenidos — más de 10.500 solo en Asturias — serían procesados por tribunales militares ${ }^{58}$.

La reacción contrarrevolucionaria se materializó en una coalición parlamentaria entre la CEDA, Renovación Española, la Comunión Tradicionalista y otros partidos de derechas contra el «impunismo». Sus diputados reclamaban una política de seguridad más militarista y la aplicación de la pena capital cuando lo dictaminaran los consejos de guerra. José María Fernández Ladreda exigió «una represión enérgica, justificada y precisa», arguyendo que la «política de atracción, de cordialidad y de pacificación de los espíritus» no era más que una «política de cobardía y de miedo». Después elogió la resistencia de los guardias civiles, arrancando un aplauso en su honor, y advirtió que la «Asturias mártir» no consentiría la «bandera del impunismo», atribuyendo el mérito de la «pacificación de Asturias» a Franco y Yagüe. Santiago Fuentes Pila argumentó que no podía enviarse «a combatir a un ejército en plan de guerra» sin el amparo del Código Militar, y elogió a las guardias cívicas formadas por las organizaciones derechis$\operatorname{tas}^{59}$. Asimismo, Fernando Suárez de Tangil denunció que los diputados izquierdistas debían elegir, «o a la revolución y a la calle, o al Parlamento y a la lucha de ideas». Nadando a contracorriente, Samper defendió su «política de pacificación de los espíritus» ante la Generalitat durante el contencioso sobre la Ley de

${ }^{54}$ GONZÁLEZ CALLEJA, 2015: 75, 92, 198 y 225-235. RUIZ, 2008: 129-133 y 251-328.

${ }_{55}$ Gaceta de Madrid, 280, 7 de octubre de 1934: 194. HIDALGO, 1934: 30-31.

56 Gaceta de Madrid, 282, 9 de octubre de 1934: 228.

57 Gaceta de Madrid, 284, 11 de octubre de 1934: 259-260.

58 GIL VICO, 2019: 222.

${ }^{59}$ Diario de las Sesiones de Cortes, 117, 7 de noviembre de 1934: 4584-4585, 4588-4589 y 4603. 
Contratos de Cultivo, y las medidas que había tomado para abortar la revolución en otras regiones. Arguyó que las carencias del Estado no estaban en el aparato coercitivo, sino en la policía de investigación ${ }^{60}$ :

... el Estado es invencible cuando pone en uso todos los resortes de su poder, pero el Estado español es débil respecto a las medidas de previsión; el Estado español no tiene montada la organización policiaca de tal manera que pueda conocer, por medio de los órganos adecuados y de las confidencias, las noticias que debe saber para adoptar certeramente las medidas oportunas de previsión ${ }^{61}$.

Por desgracia, su certero diagnóstico cayó en saco roto. Antonio Goicoechea le reprendió por no haber recuperado en junio el control del orden público en Cataluña ${ }^{62}$. Joaquín Manglano defendió que no bastaba con reforzar las policías porque a veces era necesario recurrir al Ejército, aunque Luis Rodríguez de Viguri matizó que su misión era esperar «firme y robusto» en sus cuarteles para que la Guardia Civil se sintiera respaldada ${ }^{63}$. José María Lamamié de Clairac exigió una depuración que eliminara las infiltraciones de la masonería y propuso que Franco sustituyera a Hidalgo para que hubiera «un Ministro de verdad, que sería bien recibido por el Ejército y por España entera» ${ }^{64}$. Álvarez Valdés denunció que el miedo de ciertos gobernantes a parecer poco liberales les había impedido aplicar políticas más rigurosas y propuso construir para la Benemérita «cuarteles a manera de fortines». Como colofón, Gil Robles explicó que la confianza de la CEDA estaba condicionada a la adopción de una «política firme», y presentó una segunda proposición para que las Cortes declarasen su «incompatibilidad moral» con los diputados implicados en la rebelión y exigieran el cierre de las entidades obreras involucradas. La propuesta salió adelante por 161 sufragios contra 13, con el respaldo de la minoría radical y los votos en contra de la Lliga y Unión Republicana ${ }^{65}$.

La revolución fue construida en la memoria corporativa de guardias y policías como una auténtica guerra. Batallas como la resistencia numantina del cuartel de Sama de Langreo o la defensa de Oviedo se reinventaron como episodios míticos, en los cuales los «soldados del orden» habían actuado como «vanguardia del Ejército»y cientos de héroes se habían inmolado, ganándose el «nimbo deslumbrante del martirologio» ${ }^{66}$. Hasta la revista Policía Española,

${ }^{60}$ Diario de las Sesiones de Cortes, 118, 8 de noviembre de 1934: 4619, 4623 y 4626-4627.

${ }^{61}$ Diario de las Sesiones de Cortes, 118, 8 de noviembre de 1934: 4627.

${ }^{62}$ Diario de las Sesiones de Cortes, 118, 8 de noviembre de 1934: 4633.

${ }^{63}$ Diario de las Sesiones de Cortes, 119, 9 de noviembre de 1934: 4669 y 4673.

64 Diario de las Sesiones de Cortes, 121, 14 de noviembre de 1934: 4752-4756.

${ }^{65}$ Diario de las Sesiones de Cortes, 122, 15 de noviembre de 1934: 4805-4811, 4815-4816 y 4819.

${ }^{66}$ Policía Española, 2 de noviembre de 1934: 11-12. Revista Técnica de la Guardia Civil, noviembre de 1934: 425.

Hispania, 2021, vol. LXXXI, n. ${ }^{\circ}$ 269, septiembre-diciembre, págs. 683-711, ISSN: 0018-2141, e-ISSN: 1988-8368 https://doi.org/10.3989/hispania.2021.017 
conocida por su retórica civilista, demandó para los guardias de Seguridad «recompensas militares», argumentando que habían actuado «revestidos del carácter militar» y bajo mando castrense ${ }^{67}$. Los cuadros de la milicia aprovecharon la coyuntura para extender su influencia sobre las fuerzas policiales. Por ejemplo, el comandante militar de Vizcaya, que presumía de haber vertido los «carmines de su roja sangre» igual que en Africa, arengó a sus hombres describiendo al Cuerpo de Seguridad como «continuación del Ejército» y a los guardias civiles como «viejos soldados» que conformaban el «florón que adorna al Ejército» ${ }^{68}$.

Las presiones militaristas y las referencias a las guerras coloniales aparecieron también en la prensa conservadora. El Debate defendió que el único remedio era que los dirigentes revolucionarios fueran «castigados con ejemplaridad y justicia». El rotativo presionó a Lerroux para que no intentara «armonizar lo imposible por debilidad» como Kerenski, exigiéndole que prohibiera los diarios y cerrara los centros obreros ${ }^{69}$. Por otra parte, José María Salaverría, en un artículo en $A B C$, aseveró que la Guardia Civil, comparándola con los Tercios de Flandes, era «la tropa hecha para los menesteres civiles, pero que actúa en lo civil con el estímulo más profundo de la milicia: el honor». La novedad de aquel entonces era que el «guardia de la paz pública» ya no era el agente que patrullaba las manzanas, sino un «soldado en guerra. De esta guerra civil que se ventila por calles y carreteras», que equiparaba con el «paqueo del Rif» y las guerras con los «ñádigos de Cuba»o los «asesinos juramentados del Katipunán filipino» ${ }^{70}$.

Asturias fue, evidentemente, el territorio donde la militarización de los sistemas judicial y policial fue más intensiva. Allí se constituyeron una Auditoría y una Fiscalía militares encargadas de aplicar el fuero castrense ${ }^{71}$. Para centralizar el mando de la Guardia Civil y la Policía se creó el cargo de delegado del ministro de la Guerra para el orden público, siendo nombrado Lisardo Doval ${ }^{72}$. El comandante del instituto orquestó una represión metódica, terrorífica e indiscriminada de las organizaciones obreras a base de delaciones, palizas, torturas y asesinatos, que se sumarían al del periodista Luis de Sirval a manos del teniente de la Legión Dimitri Ivanov ${ }^{73}$. Poco después, se designó a un gobernador civil general para Asturias y determinados partidos judiciales de León, Palencia y Santander, aunque durante el estado de guerra estaría subordinado a la autoridad militar y ejercería las funciones que esta no asumiera ${ }^{74}$.

${ }^{67}$ Policía Española, 2 de diciembre de 1934: 7-8.

${ }_{68}$ Policía Española, 2 de noviembre de 1934: 11-12.

${ }^{69}$ El Debate, Madrid, 13 de octubre de 1934: 1.

$70 A B C$, Madrid, 11 de octubre de 1934: 3-4.

71 Gaceta de Madrid, 287, 14 de octubre de 1934: 332.

${ }^{72}$ Gaceta de Madrid, 306, 2 de noviembre de 1934: 928.

73 RUIZ, 2008: 340-352. GIL VICO, 2019: 164-168, 193-220.

74 Gaceta de Madrid, 314, 10 de noviembre de 1934: 1179-1180. 
La represión posrevolucionaria devino un problema omnipresente en las crisis gubernativas subsiguientes. El 1 de noviembre el presidente de la República consiguió que el Gobierno indultara la pena de muerte de los responsables del aparato policiaco catalán: Joan Ricart, Enric Pérez Farràs y Federic Escofet, no solo la de este último, tras solicitar un informe al Tribunal Supremo. Considerándolo una coacción, Gil Robles propuso a Fanjul y Goded que presionaran a Alcalá Zamora para que diera marcha atrás, pero, tras sondearlo, respondieron que no podían contar con el Ejército. Aunque el informe no resultó favorable, el 5 de noviembre el gabinete refrendó los indultos y los ministros cedistas no dimitieron. Respecto a los consejeros de la Generalitat, incluido Companys, la mayoría del Gobierno opinaba que debía juzgarlos un consejo de guerra, si bien Don Niceto maniobró nuevamente para que se ocupara el Tribunal de Garantías Constitucionales, a diferencia de Azaña, que sería procesado por el Supremo ${ }^{75}$.

Aprovechando el clima contrarrevolucionario, las Cortes sancionaron una ley que incrementaba la Guardia de Asalto en 4.000 hombres, los Escuadrones de Seguridad en 206 efectivos y la Benemérita en 3.804 guardias, además de 549 jefes, oficiales, suboficiales y clases de tropa ${ }^{76}$. A ello se sumaba la incorporación de los alumnos de la Escuela de Policía Española, cuyos cursos finalizaron antes para que pudieran ingresar en el Cuerpo de Investigación ${ }^{77}$. La Cámara también restableció la pena de muerte para los delitos de terrorismo con explosivos o robo con violencia o intimidación a mano armada que causaran homicidio o lesiones graves $^{78}$. Por otra parte, se autorizó a los empresarios a rescindir los contratos de aquellos trabajadores que hubieran holgado por motivos no laborales, y fue aprobada una ley que endurecía las medidas contra la posesión ilegal de armas, depósitos y sustancias explosivas ${ }^{79}$. En último lugar, para recompensar a la fuerza pública se declararon «hechos de guerra» los episodios acaecidos desde el 4 de octubre hasta que se levantara el estado de guerra ${ }^{80}$.

La reacción estatal en Cataluña trajo consigo la recentralización del aparato de seguridad. El Ejecutivo incautó los servicios transferidos a la Generalitat y dispuso que los policías en excedencia por haber pasado a su servicio y los agentes nombrados por ella ingresaran en la Policía, lo que originó malestar entre los agentes de Investigación, que exigieron que se depuraran sus respon-

75 ALCALÁ ZAMORA, 1977: 292-294 y 521-523. GIL ROBLES, 1968: 141-148. ÁLVAREZ TARDÍO, 2016: 157-159.

${ }^{76}$ Gaceta de Madrid, 290, 17 de octubre de 1934: 379-383.

77 Gaceta de Madrid, 300, 27 de octubre de 1934: 754.

78 OLIVER OLMO, 2008: 116-117.

79 Gaceta de Madrid, 307, 3 de noviembre de 1934: 964-965. Gaceta de Madrid, 331, 27 de noviembre de 1934: 1612-1613.

${ }^{80}$ Gaceta de Madrid, 333, 29 de noviembre de 1934: 1696. 
sabilidades en la rebelión ${ }^{81}$. El giro centralizador culminó con la ley de 2 de enero, que suspendió las facultades concedidas por el Estatuto al Parlamento catalán hasta que las Cortes levantaran la suspensión de garantías y acordaran restablecer el régimen de autonomía. Las funciones de la Generalitat serían asumidas por un gobernador general, Manuel Portela Valladares y, mientras tanto, una comisión estudiaría qué servicios deberían subsistir, rectificarse o revertir al Estado ${ }^{82}$. Por su parte, el general Batet disolvió los Somatenes e institucionalizó la Agrupación de Acción Ciudadana Armada, una guardia cívica integrada por antiguos somatenistas y simpatizantes de los partidos derechistas que habían cooperado con el Estado, para que auxiliara a la fuerza pública, ratificando la desprofesionalización del ejercicio de la violencia propiciada por la respuesta a la intentona revolucionaria ${ }^{83}$.

El Gobierno emitió también disposiciones para militarizar la administración de orden público a nivel general. En concreto, propuso un proyecto de ley para organizar una división motorizada dotada de ametralladoras, cañones y obuses, constituida por soldados voluntarios que tendrían preferencia para ingresar en los institutos armados, el Cuerpo de Seguridad y otras policías ${ }^{84}$. Sin embargo, el impacto en la opinión pública nacional e internacional de las brutalidades cometidas por el Estado en Asturias le obligó a moderar la represión. De una parte, suprimió el cargo de delegado del ministro de la Guerra, cesando a Doval y transfiriendo sus funciones al gobernador general, aunque aclarando que las fuerzas de la comandancia militar exenta constituirían el «núcleo» del dispositivo de seguridad ${ }^{85}$. De otra, a finales de enero levantó el estado de guerra, sustituyéndolo por el de alarma, excepto en Asturias, Cataluña, Madrid, Aragón, Navarra, Guipúzcoa, Vizcaya, Palencia, Santander, León, Marruecos, Ceuta y Melilla ${ }^{86}$.

Un punto capital de la agenda de Vaquero fueron unos proyectos de ley cuya finalidad era militarizar la Policía. El dedicado al Cuerpo de Investigación, publicado el 9 de diciembre, aunque proponía crear una «Escuela Superior de Investigación» donde se formaran la mitad de los agentes que aspiraran a incorporarse a la escala superior y alargar los cursos de la Escuela de Policía hasta dos años, prescribía la constitución de un «Cuerpo de Vigilancia» que incluiría una Sección de «agentes de Vigilancia uniformados», formada por los agentes auxiliares de tercera - muchos de los cuales eran sargentos o suboficiales del

${ }^{81}$ Gaceta de Madrid, 331, 27 de noviembre de 1934: 1613. Gaceta de Madrid, 335, 1 de diciembre de 1934: 1793.

${ }^{82}$ Gaceta de Madrid, 3, 3 de enero de 1935: 82-83. MERA COSTAS, 2015: 122-124.

${ }^{83}$ El Benemérito Español, Barcelona, agosto de 1935: 37-38.

${ }^{84}$ Gaceta de Madrid, 335, 1 de diciembre de 1934: 1787-1788.

${ }^{85}$ Gaceta de Madrid, 343, 9 de diciembre de 1934: 2027.

${ }^{86}$ Gaceta de Madrid, 24, 24 de enero de 1935: 707. 
Ejército-y donde los efectivos de los institutos armados y el Cuerpo de Seguridad tendrían facilidades de ingreso ${ }^{87}$. Al mes siguiente, se publicó otro proyecto referido al último cuerpo. Pese a que consignaba que los jefes y oficiales del Ejército serían dados de baja en sus armas y se constituiría un Cuerpo de Suboficiales para que las clases de Seguridad pudieran ascender, reservándoles una de cada tres vacantes de oficiales, modificaba la organización territorial imitando la de la Guardia Civil, disponía la construcción de pabellones junto a los cuarteles para que los policías pudieran vivir con sus familiares y reservaba a los veteranos plazas en la Escuela de Policía para que ingresaran en el Cuerpo de Investigación y otras fuerzas menores, con el objetivo de extender la militarización organizativa y técnica al resto de policías ${ }^{88}$. Este texto, en cuya redacción participó Muñoz Grandes, tampoco resultó aprobado, aunque sería reveladoramente recuperado en 1941 para organizar la Policía Armada franquista — «los grises»— 89 .

Los proyectos anteriores pusieron fin a la unidad que había emergido en la policía, fruto de la expansión experimentada por el culto a los caídos. Respecto al Cuerpo de Investigación, Policía Española criticó la división en dos escalas, propuso que en el cuerpo uniformado solo pudieran ingresar los guardias de Seguridad mientras hubiera voluntarios y rechazó la fundación de nuevos cuerpos, proponiendo que los agentes auxiliares ingresaran en la última escala ${ }^{90}$. Su revista particular, Investigación, condenó con mayor firmeza la creación del cuerpo uniformado, la permanencia de los vigilantes en la escala técnica de la corporación y la posibilidad de que pudieran acceder a la escala superior ${ }^{91}$. En cuanto al proyecto del Cuerpo de Seguridad, su principal portavoz, iPresente...!, respaldó su militarización inspirada en el modelo de la Guardia Civil, aunque criticó la reducción del salario real y la edad de jubilación ${ }^{92}$. Investigación, en contraposición, no consideraba necesario militarizarlo para que obtuviera más respeto, sostuvo que la rigidez del Código Militar era incompatible con la flexibilidad que debía exhibir con los ciudadanos y condenó su exclusión de la Policía Gubernativa ${ }^{93}$.

La publicación profesional que adoptó una retórica más militarista fue la Revista Técnica de la Guardia Civil. Sus lectores sintonizaron a la perfección con los planes de Vaquero, que declaró que «el sentimiento republicano obliga

\footnotetext{
${ }^{87}$ Diario de las Sesiones de Cortes, 143, Apéndice 5. ${ }^{\circ}, 20$ de diciembre de 1934: 1-5. COMÍN COLOMER, 1966: 11-13.

88 iPresente...!, Madrid, 1 de enero de 1935: 8-11. Investigación, Madrid, 29 de enero de 1935: 1-3.

${ }^{89}$ PALACIOS CEREZALES, 2011: 633-634.

90 Policía Española, 2 de enero de 1935: 7-10.

91 Investigación, 9 de diciembre de 1934: 8-9. Investigación, 9 de enero de 1935: 1-9.

92 iPresente...!, 15 de enero de 1935: 3. iPresente...!, 1 de febrero de 1935: 3.

93 Investigación, 19 de enero de 1935: 12.
} 
a fortalecer al Estado, dotándolo de todos los recursos de defensa» y «sembrando en los guardadores del orden interior satisfacción», para que fuera más fuerte que el de la Monarquía. La revista demandó para el instituto el mismo armamento que el Ejército, especialmente en Asturias, que era representada como una zona de posguerra todavía por pacificar. Lamentando lo poco que habían aprendido del «ilustre compañero Doval», la publicación propuso un «estudio topográfico-militar» que permitiera elaborar planes de contingencia y establecer cuarteles fortificados en puntos estratégicos dotados de armas de parapeto, bombas de mano y fusiles. Paralelamente, en Madrid, Barcelona y Sevilla planteó organizar el "Grupo de vanguardia», una fuerza motorizada equipada con fusiles, ametralladoras, morteros, cañones, granadas, lanzallamas y lanzagases ${ }^{94}$.

Vaquero sí consiguió militarizar, no obstante, otras policías de menor entidad. Primero, fue aprobado el nuevo reglamento del Cuerpo de Guardería Forestal. El texto lo reorganizaba en un «sentido ligeramente militar». La Guardia Civil controlaría su armamento, adiestramiento y disciplina, y un jefe del instituto sería destinado a la Dirección General de Montes, Pesca y Caza para que ejerciera como enlace con la Inspección General. Asimismo, cuando se declarara el estado de guerra, sus efectivos quedarían militarizados y serían considerados «fuerza armada» en caso de agresión, permaneciendo bajo el amparo del Código de Justicia Militar ${ }^{95}$. De esta manera, la Benemérita consolidaba su hegemonía policial y obtenía presencia en otro ministerio civil: el de Agricultura. La siguiente policía militarizada fue el Cuerpo de Vigilantes de Caminos. El nuevo reglamento, publicado el 13 de marzo, le imprimiría un aire más marcial: el jefe y los oficiales procederían del Ejército o los institutos asimilados; su instrucción, disciplina y régimen interno se regirían por normas militares; y su personal estaría sometido tanto al fuero militar como a la legislación general del funcionariado ${ }^{96}$.

La militarización continuó desarrollándose ese mes mediante dos disposiciones. Por un lado, el día 1 se prorrogaron los estados excepcionales declarados en los distintos territorios, salvo en Huesca, Navarra, Santander y Teruel, donde el de alarma sustituyó al de guerra ${ }^{97}$. Por otro, se permitió a las autoridades castrenses conceder cruces del Mérito Militar, con distintivo blanco y sin pensión, a miembros de las guardias cívicas que habían cooperado con el Estado en octubre ${ }^{98}$. Esto sancionó una tendencia novedosa del proceso milita-

${ }^{94}$ Revista Técnica de la Guardia Civil, febrero de 1935: 75-76 y 70-72. Revista Técnica de la Guardia Civil, marzo de 1935: 104.

${ }_{95}$ Gaceta de Madrid, 31, 31 de enero de 1935: 903-904.

96 Gaceta de Madrid, 72, 13 de marzo de 1935: 2091-2095.

97 BALLBÉ, 1985: 378.

98 Gaceta de Madrid, 62, 3 de marzo de 1935: 1866. 
rizador a nivel simbólico: la trascendencia de las fronteras del campo burocrático propiamente dicho y su creciente influencia sobre la sociedad civil.

\section{ASEDiO AL PODER CIVIL: RIVALIDAdES INTERMinisteriales Y EXPANSIONISMO MILITARISTA}

A finales de marzo, el indulto de los socialistas asturianos Ramón González Peña y Teodomiro Menéndez provocó otra crisis de Gobierno. Los tres ministros cedistas que habían votado en contra, junto al agrario José María Cid y el reformista Joaquín Dualde, presentaron su dimisión y Lerroux, al verse desasistido, hizo lo mismo. Alcalá Zamora le encargó entonces constituir un gabinete que gobernara transitoriamente con las Cortes cerradas, formado por radicales, progresistas, independientes y dos militares: nació así el «Gobierno de los Treinta días», en el que Portela asumió la cartera de Gobernación ${ }^{99}$. El político pontevedrés implementó una política de seguridad más distendida. El 13 de abril sustituyó el estado de guerra, allí donde seguía vigente, por el de alarma, mientras que, en el resto de España, este último dio paso al de prevención, excepto en Huesca, Navarra, Palencia, Santander y Terue ${ }^{100}$. Cuatro días después suspendió las disposiciones que habían alterado el régimen estatutario en Cataluña, sin perjuicio de lo que se resolviera en aplicación de la ley de 2 de enero y excluyendo los servicios policiales, que seguían dependiendo del Estado $^{101}$. Porque, a diferencia del reformismo de Azaña, el civilismo portelista no contemplaba la descentralización del sistema de orden público.

Contrariamente al criterio de Alcalá Zamora, el 6 de mayo Lerroux formó Gobierno con cedistas, agrarios y liberal-demócratas. Este gabinete no solo incorporó a cinco ministros de la CEDA, sino que asignó a Gil Robles el Ministerio de la Guerra, aunque como contrapartida Portela mantuvo su puesto. El político salmantino presionó para militarizar los cuerpos policiales e influir en la designación de sus cuadros con el propósito de hacer de Gobernación «una sucursal de su Ministerio». Para lograrlo, promocionó a generales contrarios o escasamente leales al régimen como Franco (jefe del Estado Mayor Central), Fanjul (subsecretario de Guerra) o Goded (director general de Aeronáutica) ${ }^{102}$. Portela aguantó el envite manteniendo la Guardia Civil en su órbita y colocando bajo su dependencia la Oficina de Información y Enlace de la DGS. Una importante victoria fue la sustitución del director general de Seguridad, José

\footnotetext{
99 ALCALÁ ZAMORA, 1977: 301-304. MERA COSTAS, 2015: 156-158.

100 Gaceta de Madrid, 105, 15 de abril de 1935: 362.

101 Gaceta de Madrid, 108, 18 de abril de 1935: 563.

102 PORTELA VALLADARES, 1988: 147. ALCALÁ ZAMORA, 1977: 334-335. ÁLVAREZ TARDÍO, 2016: 170-173.
} 
Valdivia, por el nuevo subdirector e inspector general, Ramón Fernández Mato. También consiguió la dimisión de Muñoz Grandes al frente del Cuerpo de Seguridad, si bien su sustituto, el teniente coronel Rafael Fernández López, defendería una línea militarista semejante. Pero nada pudo hacer ante al nombramiento como jefe superior de Policía de Madrid de Santiago Martín Báguenas, conocido por las brutales prácticas que había promovido en Barcelona durante los años veinte. ${ }^{103}$.

Portela marcó distancias con sus predecesores elaborando un discurso liberal de la seguridad. Creía que la prerrogativa del Ejecutivo era «mantener el orden público y garantizar el derecho», y que la única forma de consolidar el régimen era construyendo una «República de orden» sobre el principio de autoridad y el respeto de los derechos individuales. También era más renuente a utilizar al Ejército y declarar el estado de guerra por el riesgo que conllevaba para la supremacía del poder civil. Para Portela, el orden no consistía en «la violencia del fusil despejando la calle o el sable amenazando las cabezas», porque la «represión que excede de una línea lo que es necesario» deviene en «agente de desorden». Sin embargo, consideraba que hasta que no se alcanzara «un estado de conciliación, de templanza, de invitación a la no violencia», no debía concederse «vía libre a los derechos y a las garantías constitucionales». En su opinión, el mejor recurso para conseguirlo, sin «acudir a operaciones de cirugía», era el estado de excepción, que no debía preocupar a los ciudadanos «honrados». Con su utilización, Portela no pretendía apuntalar el Estado, sino la libertad, que concebía como un valor inseparable del orden. La tranquilidad de España, a su juicio, no podía estar «a merced de 300 señores que quieren malparar la libertad», porque es «absurdo dejar que, por respeto a un principio, peligre el régimen en que estamos, peligre la libertad misma $\rangle^{104}$.

El proyecto de Portela se asentaba, igualmente, en la despolitización de la vía pública y una actitud más férrea contra las milicias juveniles. En verano, prohibió la exhibición de banderas, enseñas y estandartes políticos sin autorización, el empleo de uniformes y las concentraciones o marchas que encubrieran manifestaciones o ejercicios paramilitares como si fuesen actividades campestres o deportivas ${ }^{105}$. Por otra parte, el ministro concedió al Cuerpo de Seguridad el derecho a utilizar la bandera nacional por su intervención en la rebelión de octubre ${ }^{106}$. Aunque el origen castrense de este honor y el énfasis del decreto en el carácter marcial de su disciplina evidenciaban los límites del

103 MERA COSTAS, 2015: 186-190.

104 PORTELA VALLADARES, 1988: 51, 89, 127, 181 y 188. Diario de las Sesiones de Cortes, 199, 6 de junio de 1935: 7987-7988. Diario de las Sesiones de Cortes, 230, 25 de julio de 1935: 9429-9430.

105 Gaceta de Madrid, 199, 18 de julio de 1935: 649-650.

106 Gaceta de Madrid, 163, 12 de junio de 1935: 2111-2112. 
reformismo de Portela, esta medida tenía un propósito desmilitarizador, pues buscaba fortalecer la lealtad de los policías hacia su Ministerio, alejándolos de Gil Robles.

El ministro de Gobernación fortaleció también la vertiente coercitiva del aparato policiaco autorizando que los guardias de Seguridad sirvieran de paisano $^{107}$. Después se agravaron las condenas de los delitos de empleo de armas, explosivos o sustancias inflamables por móviles sociopolíticos o terroristas, elevando las sanciones máximas y prescribiendo la aplicación de la pena de muerte en más supuestos, excepto cuando hubiera ciertas circunstancias atenuantes ${ }^{108}$. No obstante, también fueron adoptadas otras medidas punitivas gracias a la presión ejercida por Gil Robles. El 28 de junio, por ejemplo, consiguió que se declarara el estado de guerra en Barcelona para contener un repunte coyuntural de la delincuencia y los atentados, pese a que Portela no lo consideraba necesario, redactando incluso el bando de promulgación ${ }^{109}$.

De manera simultánea tuvo lugar un nuevo incremento de plantillas. El 13 de julio, Portela convocó oposiciones para cubrir las vacantes de agentes de tercera clase de Investigación con la intención de reforzar la rama más civil de la policía ${ }^{110}$. Sin embargo, las Cortes aprobaron una ley, ese mismo día, que estableció que los aspirantes a ingresar en la Guardia Civil, los Carabineros, el Cuerpo de Seguridad y demás fuerzas policiales deberían haber servido tres años en el Ejército sin notas desfavorables, siendo derogadas las preferencias que disfrutaban los hijos y huérfanos de aquellas corporaciones si no habían prestado servicio al menos dos años ${ }^{111}$.

El Parlamento siguió entorpeciendo la desmilitarización del sistema de orden público militarizando la administración judicial, cuya ramificación civil era competencia del ministro cedista Cándido Casanueva. Una ley reorganizó la justicia castrense, revirtiendo las reformas impulsadas por Azaña mediante los decretos de 11 de mayo y 2 de junio de 1931 y la ley de 12 de septiembre de 1932. Las autoridades militares recobraban las tradicionales atribuciones judiciales de los capitanes generales, perdiéndolas como consecuencia los auditores, que eran profesionales del derecho pertenecientes al Ejército. No solo eso, sino que, además, se incorporaban a la Sala de Justicia Militar del Tribunal Supremo dos generales de división y dos suplentes designados por el ministro de Guerra, y el personal del Cuerpo Jurídico recuperaba su condición militar ${ }^{112}$.

107 Gaceta de Madrid, 167, 16 de junio de 1935: 2228-2229.

108 Gaceta de Madrid, 176, 25 de junio de 1935: 2411.

109 MERA COSTAS, 2015: 216-217.

110 Gaceta de Madrid, 198, 17 de julio de 1935: 626.

111 Gaceta de Madrid, 199, 18 de julio de 1935: 646-647.

112 Gaceta de Madrid, 205, 24 de julio de 1935: 807-808. 
El político gallego aprovechó agosto para ganarse el aprecio de la Guardia Civil, suavizando el requisito castrense impuesto en el reclutamiento. Portela decretó que, mientras no hubiera suficientes aspirantes que lo cumplieran, se permitiría el ingreso de aquellos escalafonados que no lo hicieran. No obstante, paralelamente emitió una medida que incomodó a los agentes de la escala técnica de Investigación: autorizó que los agentes auxiliares de tercera - que no habían pasado por la Escuela de Policía - fueran destinados a capitales provinciales, algo que se había prohibido cuando, en julio de 1931, se había organizado con ellos el Cuerpo de Policía Local, disuelto a finales de $1932^{113}$.

En septiembre, Portela promulgó unas normas para mejorar la coordinación de las policías de ámbito regional, provincial y municipal. Sus objetivos eran afianzar el mando único del Ministerio de Gobernación y corregir la privatización de la seguridad impulsada por las élites locales tras la revolución. El ministro ordenó que la Guardia Civil ejerciera funciones de mando, inspección y disciplina sobre miqueletes, miñones, mossos d'Esquadra, vigilantes de caminos, guardias forestales, guardias jurados y peones camineros, y que la Policía hiciera lo propio con los guardias municipales, si bien la Benemérita asumiría esta tarea donde no tuviera efectivos. Para implementar estas medidas se formaron juntas de coordinación de los servicios de orden público en Cataluña, Asturias y el resto de provincias, presididas por la autoridad gubernativa del territorio e integradas por los mandos de las policías pertinentes, que se encargarían de dictar instrucciones y armonizar sus reglamentos con las normas $^{114}$. Con estos decretos, Portela pretendía garantizar sus competencias frente a Gil Robles, que presentó una enmienda que no fue aprobada, descubierta por Pilar Mera Costas, para militarizar la Guardia de Asalto y facilitar una mayor intervención del Ejército en la administración de orden público ${ }^{115}$.

A resultas de los rumores sobre el caso del estraperlo, el día 25, Alcalá Zamora reemplazó a Lerroux por Joaquín Chapaprieta, que sustituyó a Portela por el radical Joaquín de Pablo Blanco. Pese a estar recomendado por Don Niceto, su mejor sintonía con Gil Robles devino en algunas disposiciones militarizadoras en materia policial. Por ejemplo, propuso que el nuevo director de Seguridad fuera Santiago Martín Báguenas, aprovechando que Lerroux había dejado preparado su nombramiento, pero Chapaprieta lo frenó

\footnotetext{
113 Gaceta de Madrid, 222, 10 de agosto de 1935: 1300 y 1309.

114 Gaceta de Madrid, 260, 17 de septiembre de 1935: 2146-2150. VAQUERO MARTÍNEZ, 2018: 490-492 y 503.

115 MERA COSTAS, 2015: 218-220. Gil Robles propuso que los mandos fueran militares o guardias civiles retirados; que la Guardia de Asalto estuviera sujeta al fuero militar y su Ministerio tuviera más peso en la concesión de destinos; y que se constituyeran unos «Batallones de Choque» que vivieran acuartelados, dependieran del Estado Mayor Central y se organizaran administrativamente como la Legión. Agradezco a la autora que me informara de su hallazgo.
} 
después de que Alcalá Zamora le transmitiera sus suspicacias ${ }^{116}$. Su siguiente medida, en cambio, fue de distensión: la permuta del estado de guerra por el de alarma en Barcelona, y el paso al de prevención en Guipúzcoa, Huesca, Navarra, Santander y Teruel ${ }^{117}$. Con la tercera pretendía suscitar una buena primera impresión en el Cuerpo de Seguridad: otro sobreseimiento de los expedientes en trámite - excepto por faltas muy graves - y la anulación de las multas, suspensiones de empleo y sueldo y pérdidas de puestos de guardias y clases, excluyendo a los de la Generalitat, cuyos expedientes de depuración seguían pendientes ${ }^{118}$.

En noviembre, de Pablo Blanco aprobó determinadas contrarreformas de peso. La más relevante fue el cierre de la Escuela de Policía, que causó indignación entre los agentes de Investigación, pues lo interpretaron como una sanción contra el cuerpo ${ }^{119}$. No obstante, al tiempo siguió restaurando las garantías constitucionales, sustituyendo el estado de alarma por el de prevención en León, Palencia, Vizcaya, Ceuta y Melilla; y restableciendo la normalidad en las otras provincias, excepto en Santa Cruz de Tenerife, donde mantuvo el de prevención, y en Asturias, Cataluña, Madrid y Zaragoza, donde subsistió el de alarma $^{120}$. Esta política no afectó a Cataluña, donde la recentralización cobró nuevo impulso mediante la creación del delegado general de Orden Público, que asumiría las competencias de seguridad de los gobernadores generales y civiles y los delegados autónomos. No resulta casual que el primer titular fuera Martín Báguenas ${ }^{121}$.

Entretanto, la Cámara sancionó una ley que aumentaba la capacidad punitiva de la Ley de Vagos y Maleantes al adicionar un párrafo que posibilitaba considerar como «peligrosos antisociales» a aquellos que incitaran a la ejecución o realizaran apología de los delitos de terrorismo o atraco ${ }^{122}$. Respecto a la Guardia Civil, de Pablo restableció el empleo de alférez para facilitar el ascenso de sus hombres a la oficialidad, algo que perjudicaba a los tenientes del Ejército y la Armada. Sin embargo, una orden posterior autorizó que ingresaran sin haber cumplido el compromiso con su arma para promover su incorporación, anulando el efecto desmilitarizador del decreto anterior ${ }^{123}$.

116 CHAPAPRIETA, 1971: 212-224 y 230-231.

117 Gaceta de Madrid, 271, 28 de septiembre de 1935: 2398. Gaceta de Madrid, 285, 12 de octubre de 1935: 247.

118 Gaceta de Madrid, 272, 29 de septiembre de 1935: 2433.

119 Gaceta de Madrid, 305, 1 de noviembre de 1935: 922-923.

120 Gaceta de Madrid, 317, 13 de noviembre de 1935: 1219.

121 Gaceta de Madrid, 324, 20 de noviembre de 1935: 1427-1428. Gaceta de Madrid, 331, 27 de noviembre de 1935: 1670.

122 Gaceta de Madrid, 332, 28 de noviembre de 1935: 1715.

123 Gaceta de Madrid, 333, 29 de noviembre de 1935: 1751 y 1775. 


\section{Desmilitarizar la Policía: del proyecto de Vicente Santiago al «ruido DE SABLES»}

Chapaprieta dimitió el 9 de diciembre tras haber perdido el respaldo del bloque mayoritario. Gil Robles decidió negar su apoyo a cualquier gobierno que no presidiera él mismo, si bien Alcalá Zamora continuó sin ofrecérselo. Para impedir la disolución de las Cortes, el líder salmantino propició que Franco, Fanjul, Varela y Goded evaluaran la posibilidad de rebelarse y, aunque no ofreció su concurso explícitamente, sí prometió que no interferiría, pero Franco concluyó que no era el momento. Fue Portela quien finalmente formó Gobierno, incorporando a dos militares y ocupándose del Ministerio de Gobernación, con la misión de organizar las próximas elecciones ${ }^{124}$.

El político liberal retomó su agenda profesionalizadora impulsado por la prensa policial, que presionó para que rectificara las contrarreformas militarizadoras de sus antecesores. Primero, sustituyó al director general de Seguridad, José Gardoquí, por Vicente Santiago, y al inspector general de la Guardia Civil, Miguel Cabanellas, por Sebastián Pozas. Después envió unas normas a jueces, auditores y jefes militares para que aceleraran la actividad de los consejos de guerra, con el objetivo de restablecer la preponderancia de la justicia civil cuanto antes. A continuación, paralizó el cierre de la Escuela de Policía y ordenó la redacción del plan de estudios de la siguiente promoción. En último lugar, forzó la dimisión de Martín Báguenas en Cataluña y transigió con la restitución del Somatén porque necesitaba el apoyo de la Lliga, pero se aseguró de que la Benemérita fiscalizara su reclutamiento, organización y disciplina ${ }^{125}$.

Portela continuó firmando disposiciones de tono desmilitarizador en el mes de febrero. De una parte, consiguió que la Junta Central del Censo ratificara el derecho de voto de los guardias de Seguridad, arguyendo que era un cuerpo «esencialmente civil» que estaba militarizado solo en lo tocante a la obediencia a sus jefes y el mantenimiento de la disciplina, y levantó todos los estados de excepción cuando arrancó la campaña electoral ${ }^{126}$. De otra, encargó a Santiago la redacción de un proyecto de reglamento policial que consolidara su carácter civil; sin embargo, no llegaría a ser ratificado ${ }^{127}$.

Como es sabido, los comicios generales se celebraron el 16 de aquel mes. Respondiendo a la escalada de desórdenes impulsada por los manifestantes del

124 GIL ROBLES, 1968: 355-375. MERA COSTAS, 2015: 239-251. ÁLVAREZ TARDÍO, 2016: 197-199.

125 Gaceta de Madrid, 360, 26 de diciembre de 1935: 2586-2587. VAQUERO MARTÍNEZ, 2018: 499-503.

${ }^{126}$ Gaceta de Madrid, 40, 9 de febrero de 1936: 1228-1229. Gaceta de Madrid, 8, 8 de enero de 1936: 203.

127 Policía Española, 16 de enero de 1936: 9-10. 
Frente Popular para precipitar el traspaso de poderes y la aprobación de la amnistía, Portela promulgó el estado de alarma. Gil Robles, Calvo Sotelo y Franco le presionaron para que declarara el de guerra y se mantuviera en el poder. No obstante, aunque Alcalá Zamora había firmado el decreto, Portela se negó, temeroso de que los militares dieran un golpe. Precisamente, Fanjul y Goded pulsaron sin éxito el sentir del Ejército y Franco sondeó a Pozas, que le advirtió que la Guardia Civil detendría cualquier rebelión. Todavía así, las autoridades castrenses de Albacete, Zaragoza, Valencia, Oviedo y Alicante, entre otras, proclamaron la ley marcial. Rodeado por ambos flancos y sin recursos bastantes para mantener el orden, el político gallego decidió presentar anticipadamente su dimisión ${ }^{128}$.

\section{Conclusión}

La militarización del sistema policial en el segundo bienio no fue constante, ni irreversible ni estaba predeterminada, sino que fue un fenómeno contingente que presentó múltiples etapas, velocidades y agentes implicados. En puridad hubo dos procesos: uno de militarización, entre septiembre de 1933 y diciembre de 1935, que se aceleró en octubre de 1934 y se desaceleró a partir de abril de 1935, y otro de desmilitarización hasta febrero de 1936. El motor de esta alternancia fue la dialéctica entre dos modelos de orden público: uno contrarrevolucionario, que conllevaba un nivel de militarización elevado, diseñado por Salazar Alonso, Vaquero y de Pablo Blanco; otro liberal, que implicaba una militarización más reducida, elaborado por Rico Avello, Portela Valladares y, parcialmente, Martínez Barrio. Dicho fenómeno estuvo causado básicamente por cinco factores de índole cultural, administrativa, política y social.

En primer lugar, los gobernantes construyeron dos discursos sobre el orden público partiendo de la creencia de que, para garantizar los derechos ciudadanos, antes debía restablecerse el principio de autoridad: el contrarrevolucionario anteponía la defensa del Estado y la neutralización del peligro revolucionario; el liberal preconizaba una «República de Orden» y abogaba por suspender las garantías constitucionales hasta extinguir el clima de violencia que hacía peligrar la libertad. Asimismo, los especialistas del orden público poseían una cultura profesional equipada con valores, protocolos e imágenes castrenses, cuya incidencia era primordial en la Guardia Civil, notable en el Cuerpo de Seguridad y minoritaria en Investigación. El segundo elemento era el aparato legal y organizativo de seguridad, particularmente la persistencia de

128 PORTELA VALLADARES, 1988: 175-196. GIL ROBLES, 1968: 492-502. MERA COSTAS, 2015: 311-322. ÁLVAREZ TARDÍO, 2016: 212-217. GONZÁLEZ CALLEJA, 2014: 332. 
estructuras, inercias y rutinas burocráticas derivadas del tradicional militarismo de la administración estatal.

Los factores políticos fueron todavía más relevantes. Por un lado, la presión que partidos derechistas, organizaciones patronales, grandes terratenientes y periódicos conservadores ejercieron sobre el Gobierno, destacando la coalición que constituyeron contra el «impunismo». Claves resultaron la actitud semileal de la CEDA, los devaneos de Gil Robles con los militares y el ineficaz intrusismo de Alcalá Zamora. También lo fue la presión del Ejército para controlar el orden público y, en menor medida, la de la Guardia Civil y el Cuerpo de Seguridad, que demandaron la reversión de las reformas y armamento de guerra. Por el otro, las políticas policiales contrarreformistas que dispusieron la restitución de la autonomía de la Benemérita, la potenciación de las fuerzas represivas sobre las preventivas, la intervención del Ejército y las tropas africanas y la militarización de determinados cuerpos policiacos. La última variable fue la evolución castrense del control policial de la acción colectiva, evidentemente correlacionada con el incremento de las protestas violentas y los atentados políticos, y con la movilización revolucionaria de anarquistas y socialistas. Especial importancia tuvo la insurrección de octubre, que desencadenó la mayor oleada militarizadora del periodo y extremó la militarización del repertorio coercitivo iniciada meses atrás.

Este proceso constituyó una tentativa de los radicales de consolidar la República mediante la construcción de un Estado fuerte que garantizara la ley y el orden. Sin embargo, sus resultados fueron enormemente contraproducentes. Los Gobiernos no apuntalaron el respaldo de la CEDA y perdieron el apoyo del republicanismo de centro y otros sectores moderados, la administración policiaca se desprofesionalizó y crecieron las divisiones internas, el Ejército recuperó su preeminencia y aumentó su peligrosidad respecto al régimen, y el incremento de la represión causó 1.054 de los 1.705 muertos del bienio. La terrorífica represión de la revolución asturiana redujo drásticamente la protesta en 1935, pero su recuerdo en 1936 posibilitaría el triunfo electoral de las izquierdas, catalizaría el empleo de la violencia política en ambos extremos y minaría la confianza policial en los protocolos incruentos de actuación. Así pues, la legitimidad que perdieron los radicales por implementar políticas más represivas en un régimen democrático no quedó compensada por una mayor eficacia porque, a largo plazo, empeoraron el problema del desorden, dejando una herencia difícil de gestionar.

\section{Bibliografía}

Alcalá Zamora, Niceto, Memorias (Segundo texto de mis Memorias), Barcelona, Planeta, 1977.

Álvarez Tardío, Manuel, José María Gil-Robles, un conservador en la República, Madrid, FAES, 2016. 
Ballbé, Manuel, Orden público y militarismo en la España constitucional (1812-1983), Madrid, Alianza, 1985.

Blaney, Gerald, Jr., «Keeping Order in Republican Spain, 1931-1936», en Gerald Blaney, Jr. (ed.), Policing Interwar Europe. Continuity, Change and Crisis, 191840, Basingstoke, Palgrave Macmillan, 2007: 31-68.

Cabrera Calvo-Sotelo, Mercedes, La patronal ante la II República. Organizaciones y estrategia (1931-1936), Madrid, Siglo XXI, 1983.

Capoccia, Giovanni, Defending Democracy. Reactions to Extremism in Interwar Europe, Baltimore, Johns Hopkins University Press, 2007.

Casanova, Julián, De la calle al frente. El anarcosindicalismo en España, Barcelona, Crítica, 2010.

Chamberlin, Foster, «Policing Practices as a Vehicle for Brutalization: The Case of Spain's Civil Guard, 1934-1936», European History Quarterly, 50/4 (Londres, 2020): 650-668.

Chapaprieta, Joaquín, La paz fue posible. Memorias de un político, Barcelona, Ariel, 1971.

Cobo Romero, Francisco, Por la reforma agraria hacia la revolución. El sindicalismo agrario socialista durante la II República y la Guerra Civil (1930-1939), Granada, Universidad de Granada, 2007.

Comín Colomer, Eduardo, Notas para la Historia de la Policía. Cuatro directores de Seguridad, Madrid, Imprenta «La Xilográfica», 1966.

Cruz, Rafael, «La Lógica de la Guerra. Ejército, Estado y Revolución en la España Contemporánea», Studia Historica. Historia Contemporánea, 10-11 (Salamanca, 1992-1993): 207-222.

Della Porta, Donatella y Reiter, Herbert, «The Policing of Protest in Western Democracies», en Donatella della Porta y Herbert Reiter (eds.), Policing Protest. The Control of Mass Demonstrations in Western Democracies, Minneapolis, University of Minnesota Press, 1998: 1-32.

Espinosa Maestre, Francisco, La primavera del Frente Popular. Los campesinos de Badajoz y el origen de la guerra civil (marzo-julio de 1936), Barcelona, Crítica, 2007.

Gil Robles, José María, No fue posible la paz, Barcelona, Ariel, 1968.

Gil Vico, Pablo, Verdugos en Asturias. La violencia y sus relatos en la revolución de Asturias de 1934, Gijón, Ediciones Trea, 2019.

González Calleja, Eduardo, En nombre de la autoridad. La defensa del orden público durante la Segunda República española (1931-1936), Granada, Comares, 2014.

González Calleja, Eduardo, Cifras cruentas. Las víctimas mortales de la violencia sociopolítica en la Segunda República española (1931-1936), Granada, Comares, 2015.

Hidalgo, Diego, ¿Por qué fui lanzado del Ministerio de la Guerra? Diez meses de actuación ministerial, Madrid, Espasa-Calpe, 1934.

Lerroux, Alejandro, La pequeña historia de España: 1930-1936, Barcelona, Mitre, 1985.

Lleixà, Joaquim, Cien años de militarismo en España, Barcelona, Anagrama, 1986.

López Garrido, Diego, El aparato policial en España. Historia, sociología e ideología, Barcelona, Ariel, 1987. 
López Martínez, Mario, Orden público y luchas agrarias en Andalucía. Granada, 1931-1936, Madrid, Ediciones Libertarias / Ayuntamiento de Córdoba, 1995.

Martínez Barrio, Diego, Memorias, Barcelona, Planeta, 1983.

Mera Costas, Pilar, Monárquico, republicano, liberal. Biografía política de Manuel Portela Valladares, tesis doctoral, Universidad Complutense de Madrid, 2015.

Oliver Olmo, Pedro, La pena de muerte en España, Madrid, Síntesis, 2008.

Palacios Cerezales, Diego, Estado, régimen y orden público en el Portugal contemporáneo, tesis doctoral, Universidad Complutense de Madrid, 2008.

Palacios Cerezales, Diego, «Ansias de normalidad. La policía y la República», en Fernando del Rey (dir.), Palabras como puños. La intransigencia política en la Segunda República española, Madrid, Tecnos, 2011: 596-646.

Portela Valladares, Manuel, Memorias. Dentro del drama español, Madrid, Alianza, 1988.

Rey, Fernando del, Paisanos en lucha. Exclusión politica y violencia en la Segunda República española, Madrid, Biblioteca Nueva, 2008.

Risques Corbella, Manel, L'Estat a Barcelona. Ordre públic i governadors civils, Barcelona, Base, 2012.

Ruiz, David, Octubre de 1934. Revolución en la República española, Madrid, Síntesis, 2008.

Salazar Alonso, Rafael, Bajo el signo de la Revolución, Madrid, Imp. Sáez Hermanos, 1935.

Souto Kustrín, Sandra, «Y ¿Madrid? ¿Qué hace Madrid?». Movimiento revolucionario y acción colectiva (1933-1936), Madrid, Siglo XXI, 2004.

Townson, Nigel, La República que no pudo ser. La política de centro en España (1931-1936), Madrid, Taurus, 2002.

Townson, Nigel, «De Oviedo a la Puerta del Sol, Manuel Rico Avello en la Segunda República, 1931-1933», en Juan Pan-Montojo (coord.), El sueño republicano de Manuel Rico Avello (1886-1936), Madrid, Biblioteca Nueva, 2011: 77-120.

Vaquero Martínez, Sergio, «De la ebullición a la contrarrevolución. Los significados del orden público en los libros de los gobernantes de la Segunda República española, 1931-1936», Espacio, Tiempo y Forma. Serie V, Historia Contemporánea, 28 (Madrid, 2016): 187-213.

Vaquero Martínez, Sergio, La democratización del orden público en la Segunda República española: cultura, política y policía, 1931-1936, tesis doctoral, Universidad Complutense de Madrid, 2018.

Vidarte, Juan Simeón, El bienio negro y la insurrección de Asturias. Testimonio del que fue vicesecretario y secretario del PSOE, Barcelona, Grijalbo, 1978.

Villa García, Roberto, La República en las urnas. El despertar de la democracia en España, Madrid, Marcial Pons, 2011.

Recibido: 23/11/2019

Aceptado: 28/01/2021 